\title{
DO POST-SOCIALIST URBAN AREAS MAINTAIN THEIR SUSTAINABLE COMPACT FORM? ROMANIAN URBAN AREAS AS CASE STUDY
}

\author{
Simona Raluca GRĂDINARU*, Cristian Ioan IOJĂ*, Ileana PĂTRU-STUPARIU ${ }^{* *}$ \\ "University of Bucharest, Centre for Environmental Research and Impact Studies, \\ Romania; "University of Bucharest, Institute of Research - ICUB, \\ Transdisciplinary Research Centre Landscape-Territory-Information Systems - \\ CeLTIS; Department of Regional Geography and Environment, \\ Faculty of Geography, Romania
}

\begin{abstract}
The compact city is regarded as an important concept in promoting sustainable development, especially within the European Union. The socialist urban planning system maintained a high compactness of the urban areas through almost exclusive predominance of the public sector in housing provision, and ideological nature of the planning strategies. After the 1990's, the administrative decentralization allowed local authorities to adopt particular urban development strategies. However, development was directly influenced by the importance of the urban administrative centre. The aim of the paper is to determine if post-socialist urban areas maintained their compact urban form or they encountered different evolution trajectories. We determined the type of changes by calculating urban form indicators at two time moments: 1990 and 2006. Furthermore, the two-way repeated-measurement ANOVA was used to identify significant changes, and to assess the effect of the development level of the urban area on the variance of form indicators. The results show that Romanian post-socialist urban areas either shifted from the compact form, "inherited" after the collapse of socialism, to more dispersed patterns, either expanded in a compact manner. Moreover, as development level got higher, urban areas were more likely to be affected by suburbanization and periurbanization. In order to respond to these challenges, new instruments such as setting of metropolitan areas or spatial framework plans could be used. Furthermore, planning should be adapted to local circumstances and to the different development trajectories of big and mid-sized urban areas.
\end{abstract}

Key Words: compactness, development level of urban areas, functional areas, horizontal planning.

\section{Sustainability of urban areas as reflected by the urban form}

The concept of urban development has become increasingly significant as a target for creating a better future for the world - both economically, socially and environmentally (Munier 2011, Zhou et al. 2015). Within this situation, sustainable urban development plays an important role in achieving global sustainability targets. Thus, to "make cities and human settlements inclusive, safe, resilient and sustainable" is the specific urban goal proposed in 2014 by the Open Working Group on Sustainable Development Goals for United Nations' Millennium Development Goals.

At the European Union level, the idea of moving from urban sprawl to a 'compact city' has been proposed as one way to achieve improved urban sustainability (European Commission 1990, 2014). The concept became central in the sustainable development debate and it consequently translated into policy and practice (Burton 2002). Strategies on revitalisation and regeneration of inner-urban areas, built-up densification or reuse of brownfields were used in land use planning policy in many countries to stimulate compactness. 
Scientific research brought evidence in support of compact development (Jabareen 2006, Jenks and Burgess 2000). The claimed advantages of a compact city are well documented and they consist of increased efficiency of transport infrastructure (Gusdorf and Hallegatte 2007), lower costs for maintenance and higher performance of public utilities (Farmani and Butler 2014), much smaller areas of land used to extend the built-up environment and less landscape fragmentation (Chen et al. 2008), the ability to encourage social interaction due to high-density of built-up areas (Elkin et al. 1991), and less need to travel by car, thus reduced noise and fuel emissions.

However, the downsides of compactness should be acknowledged, especially by planners and practitioners (Burton 2002). A higher density of built-up areas is sometimes achieved through the conversion of open and green areas. Moreover, as cities become denser, they lose the ability to mitigate the urban heat island process (Cheval and Dumitrescu 2009). Such issues should be recognized and documented, as they are important in how planning decisions are taken.

Most former socialist cities are regarded as having a high degree of compactness (Hirt 2013, Sýkora and Ourednek 2007). The socialist urban planning system maintained the urban compactness through the almost exclusive predominance of the public sector in housing provision, the inhabitants' reliance on public transport that prevailed during that time and the ideological nature of planning strategies that promoted dense urbanization to foster collective identity (Halleux et al. 2012). Moreover, the patterns of urban expansion were governed by master plans devised and approved in a top-down approach.

In Romania, after the 1990's, decision-making and administrative decentralization allowed the county and local authorities to adopt particular urban development strategies (Stanilov 2007). Through projects of urban renewal, infill development or urban expansion, the authorities tried to meet the new expectations of the local communities. These projects were, however, directly influenced by the importance of the urban administrative centre and the authorities' ability to attract private investments and to support the public ones.

Scoffham and Marat-Mendes (2013) highlighted that the sustainability of an urban area lies mostly in its ability to adapt to society's needs. Local authorities should identify the means to maintain a balance between the pressures imposed by the demographic, social and technological changes (Chen et al. 2008), and to achieve the rational use of the resources necessary to support the development of built-up areas (Echenique et al. 2012).

Sustainable urban development can also be achieved through a balanced spatial structure promoted by well-coordinated spatial development policies (European Commission 1999). Thus, the role of spatial strategies is to encourage and to guide the spatial distribution of development (e.g., constructed areas and the related infrastructure), taking into account the need to preserve the environmental assets. To achieve this, a close cooperation between the authorities responsible with spatial planning at vertical and horizontal levels is needed (lanoş et al. 2012).

The term urban form is used to express the spatial configuration of the fixed elements within the urban area (Anderson et al. 1996). The scale at which urban form analysis is performed can vary from building, street, block, neighbourhood and city (Dempsey et al. 2010), to the area located in the influence zone of the city (Arribas-Bel et al. 2011).

Different approaches have been proposed to systematically analyse and classify the urban form. While some authors refer to the physical structure of the city (i.e. morphological structure as expressed by shape and disposition of the urban patches) or land use/land cover structure (Galster et al. 2001), others include also aspects related to socio-demographic and economic 
activities (Huang et al. 2007). Even so, a difference should be made between the urban form itself, as a static measure for a given moment in time, and urban growth which represents a dynamic process which alters the urban form (Schwarz 2010).

Urban form and its evolution over time are the result of a variety of factors. Natural features, such as topography or the presence of water bodies and natural risk areas, economic and demographic development, cultural background, are all elements that induce form differences (Anderson et al. 1996). Moreover, land-use policies (i.e. zoning, master plans, built-up containment limits) and planning approaches have been proven to have a strong impact over the dynamic of the urban form (Camagni et al. 2002, Zhao 2010).

Urban form dynamics highlights the relationship between the city (i.e. urban core) and its functional area (Grimm et al. 2008). The analysis which looks beyond the administrative borders of the urban core allows the identification of more efficient methods for the planning of urban areas (Aguilera et al. 2011, Schwarz 2010).

In the urban form analysis, the choice of indicators is essential. Indicators should be able to reflect the processes specific to urban expansion (Jaeger et al. 2010), such as sprawl or suburbanization, to allow researchers and practitioners to relate them to urban development strategies, and the necessity of adapting planning policies (Galster et al. 2001). Huang et al. (2007) identify four dimensions which should be covered by urban form indicators: (a) centrality, (b) complexity, (c) compactness, referring to the structure, shape and fragmentation of built-up patches, and (d) porosity, referring to the share and distribution of green areas.

The Territorial Agenda 2020 established by the EU (European Commission 2011), recommends a horizontal approach, focused on cities and their functional areas, in order to increase the sustainability of the planning process. In this case, the role played by planning becomes that of guiding urban development toward a desired form, without limiting the society's needs (Waldheim 2006). Throughout the rest of the paper, we will use the term urban area to refer to the city core and its functional area.

Post-socialist urban areas are characterized by significant administrative transformations, namely a higher importance of local and supra-local governance and the integration of public participation into the planning process (Petrișor 2010), and experience processes which were not present during the socialist times, such as urban sprawl (Suditu et al. 2010) or urban shrinkage. In the context of these transformations and urban sustainability being promoted both at European and global level through the concept of urban compactness, it becomes important to identify how post-socialist urban areas could contribute to achieving this target. Thus, the aim of the paper is to determine if post-socialist urban areas maintain their compact urban form or they encounter different evolution trajectories. Considering urban form as the result of the physical structure and the size of the urban fabric, and focusing on urban areas in Romania, the study addresses the following questions:

a) What are the spatial and temporal form changes experienced by post-socialist urban areas?

b) Is urban form dynamics connected to the development level of urban areas?

\section{Methodology for assessing the spatial and temporal dynamics of urban form}

\section{Setting the study areas}

A number of 29 urban areas in Romania (Fig. 1) were chosen for the urban form assessment. The urban areas were selected based on their location within the counties with the most severe 
expansion of the built-up space, as identified by the studies of Suditu et al. (2010) and Petrişor et al. (2010).

The first step of the analysis was to delineate the administrative boundaries of each urban core and its functional area (Fig. 2). Following the Urban Audit methodology (Bretagnolle et al. 2011) we considered urban areas as having two spatial dimensions:

a) the core city, which encompasses the administrative boundary of the city, and

b) the Larger Urban Zone (LUZ), which is an approximation of the functional urban area centred around the core.

According to the National Institute of Statistics (NIS 2013), in Romania, the designation of functional areas consisted of the aggregation of "suburban communes", namely the neighbouring rural administrative units which are urbanized, industrialized or have a high economic development level. The rural administrative units are independently governed, they have lower budgets as compared to the adjacent cities, and less opportunities to access funding for the public infrastructure development. However, they are highly vulnerable to urban sprawl, and in some cases the intensity of built-up development is higher than in the city core (Suditu et al. 2010). For urban areas on which NIS did not provided specific information, the functional areas were determined based on the law promulgated in 1968 (National Assembly 1968), which provides a detailed list of the suburban communes in Romania. The borders of the urban areas were revised in order to meet the present administrative limits (e.g. some of the suburban communes have become districts of the city core).

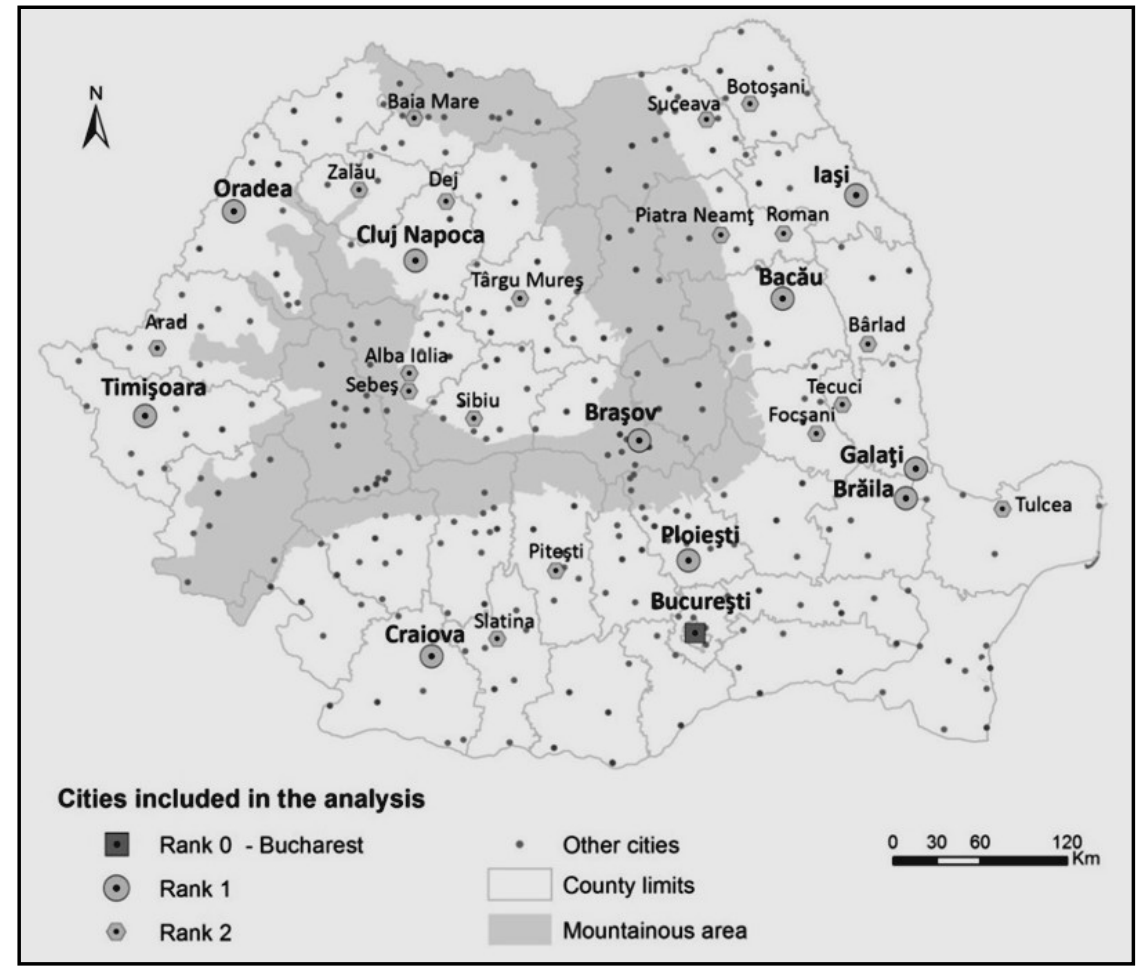

Fig. 1 - Distribution of urban areas in Romania and selected case studies 


\section{Calculation of urban form indicators}

The indicators employed to characterize the urban form cover the criteria set by Huang et al. (2007): centrality - centrality index, compactness - compactness index and compactness index of the largest patch, and porosity - porosity index (Galster et al. 2001, Schwarz 2010). "The largest patch" refers to continuous built-up areas within the city core administrative borders, without taking into account the neighbourhoods spatially detached from it.

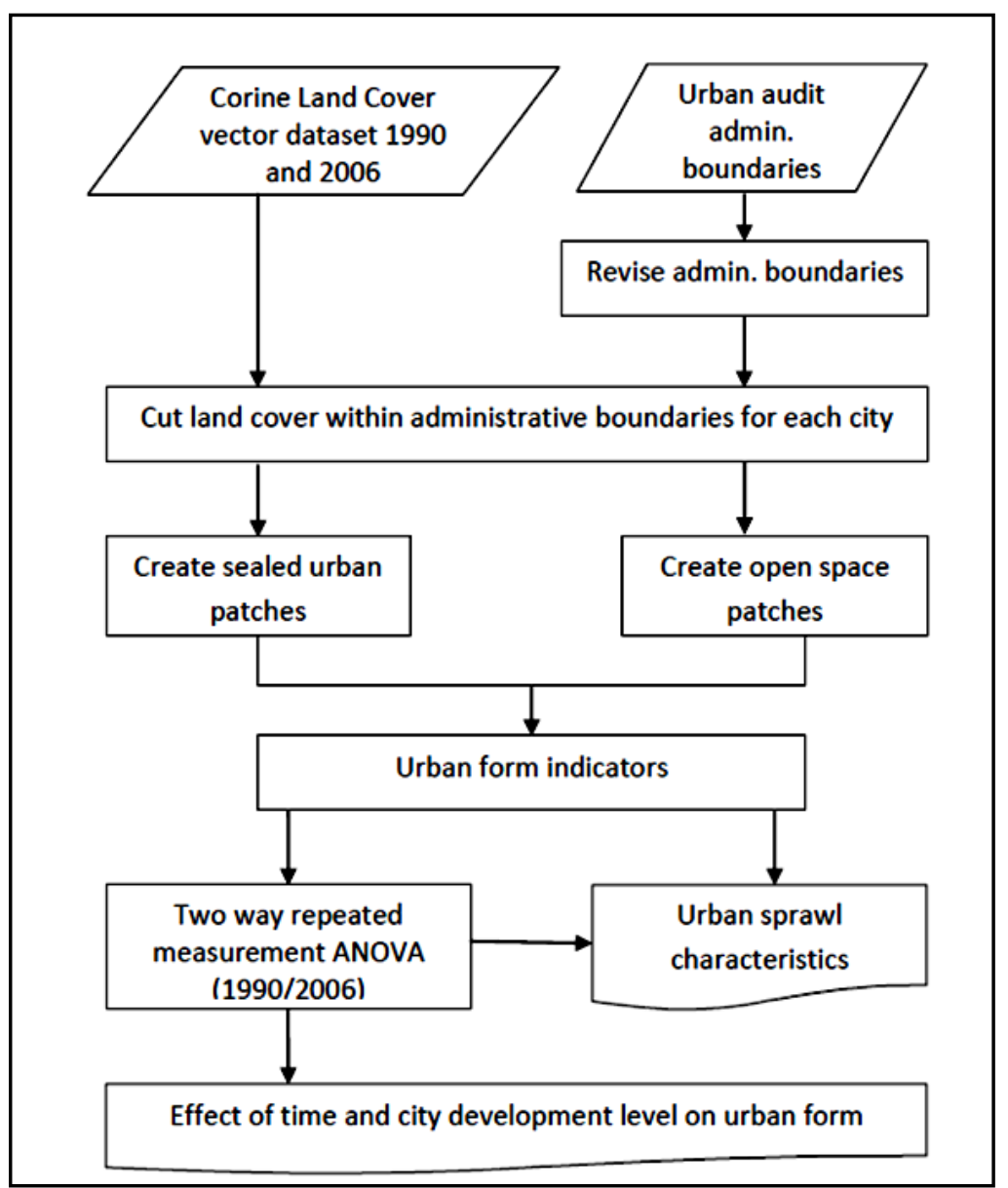

Fig. 2 - Workflow of data processing and analysis

Corine Land Cover datasets for 1990 (EEA 2013a) and 2006 (EEA 2013b) were used to derive the land cover data necessary for urban form indicators computation. The calculation of the first three indicators was based on eight land cover classes corresponding to built-up areas (Table 1 ). These classes were grouped into one category named sealed urban patches (Schwarz 2010). Porosity index takes into consideration the CLC classes corresponding to green and open spaces (Milego 2007). A detailed description of the formulas and interpretation of the four indicators is provided in Table 2. 
Table 1

Corine Land Cover classes used to set of open space and sealed urban patches

\begin{tabular}{|l|l|l|l|}
\hline $\begin{array}{l}\text { CLC } \\
\text { code }\end{array}$ & Sealed urban classes & $\begin{array}{l}\text { CLC } \\
\text { code }\end{array}$ & Green and open space classes \\
\hline 111 & Continuous urban fabric & 141 & Green urban areas \\
\hline 112 & Discontinuous urban fabric & 311 & Broad-leaved forest \\
\hline 121 & Industrial or commercial units & 312 & Coniferous forest \\
\hline 122 & $\begin{array}{l}\text { Road and rail networks and } \\
\text { associated land }\end{array}$ & 313 & Mixed forest \\
\hline 123 & Port areas & 322 & Moors and heath land \\
\hline 124 & Airports & 324 & Transitional woodland-shrub \\
\hline 132 & Dump sites & & \\
\hline 133 & Construction sites & & \\
\hline
\end{tabular}

Table 2

Urban form indicators - formulas and interpretation

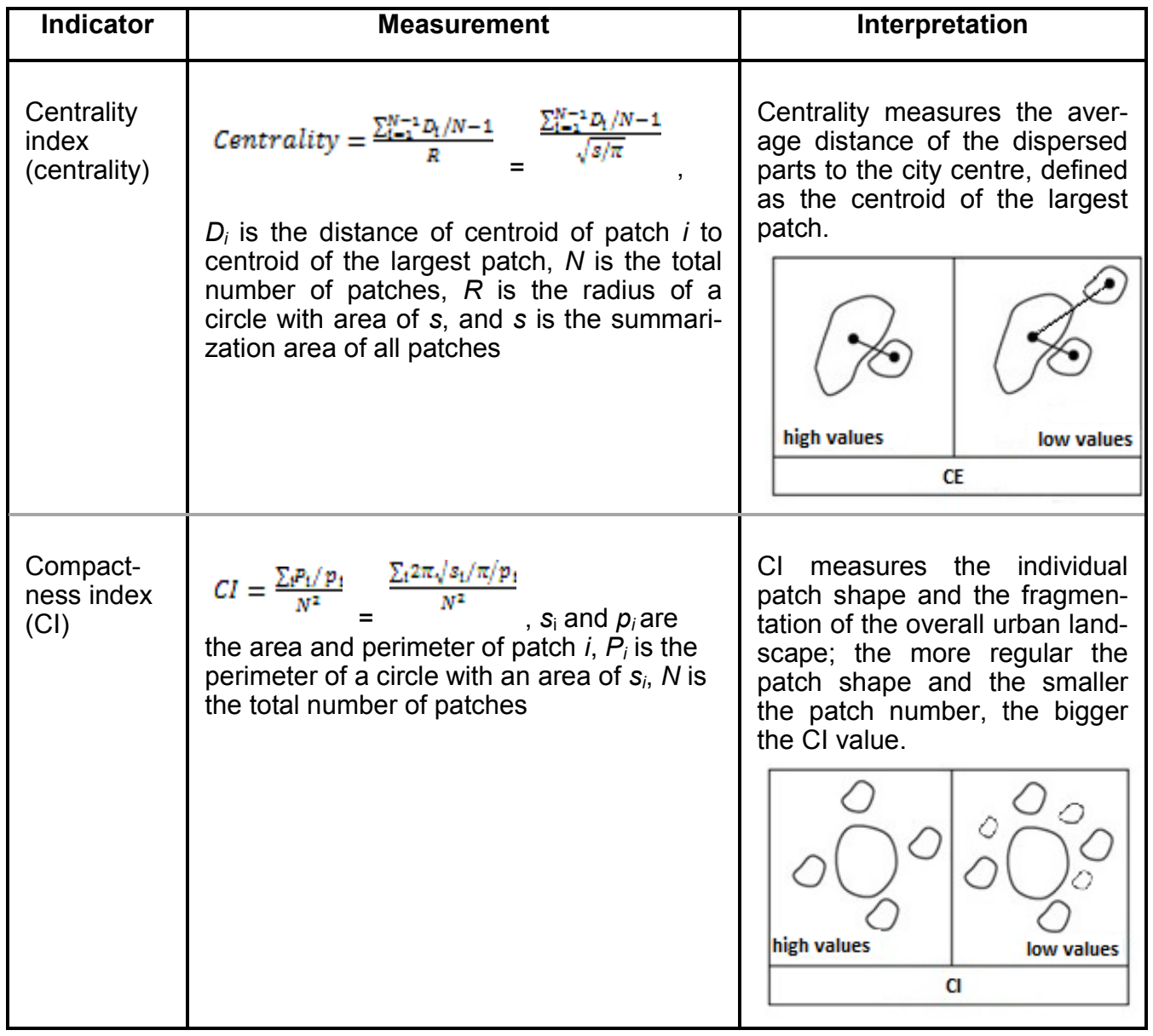

See the next page 
Do Post-Socialist Urban Areas Maintain their Sustainable Compact Form ? Romanian Urban Areas as Case Study

Urban form indicators - formulas and interpretation

Table 2

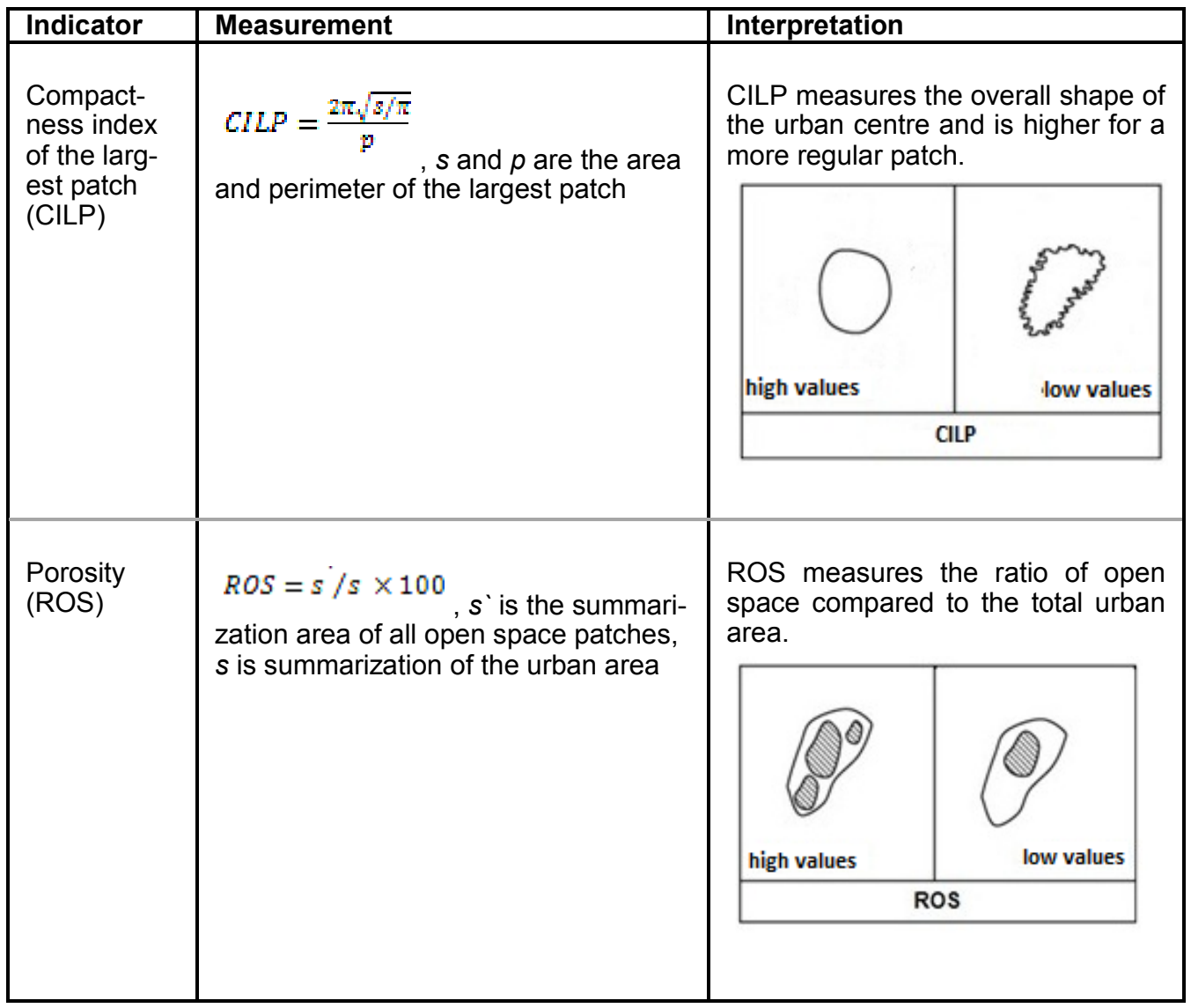

The graphical representation for urban form indicators is an interpretation after Huang et al. (2007)

\section{Analysis of urban form dynamics}

We categorized the urban areas according to the development level (DL), based on the settlement ranking in the National Spatial Plan of Romania - Section Settlements Network (Romanian Government 2001). The DL reflects the level of modernization and it is an expression of the present and near future importance of a settlement within the urban network, from an economic, administrative, political, social, economic and cultural perspective (Petrişor 2010). The DL was set as follows:

$$
\begin{aligned}
& \text { City of Rank } \\
& \text { City of Rank }\}_{1}^{0} \rightarrow \text { DL } 1 \\
& \text { City of Rank } 2 \rightarrow \text { DL } 2
\end{aligned}
$$

In order to determine the significance of urban form changes over time, as well as the effect of the DL of the urban area on the variance of form indicators we performed a two-way repeated- 
measurement ANOVA. The analysis allows observations on the effect of factors on a dependent variable (i.e. each urban form indicator). The repeated measurement design tests the following null hypotheses: a) factor 1 (e.g. time) has no effect on the urban form indicator mean; b) factor 2 (e.g. DL) has no effect on the urban form indicator mean; c) there is no interaction between factor 1 and factor 2 (Gotelli and Ellison 2013). Levene's test and Box's test were consulted for checking homogeneity of variance respectively the equality of covariance matrices assumptions (Field 2009).

\section{Results}

The results showed that the Centrality index (CE) recorded a dominant decreasing trend between 1990 and 2006 (Fig. 3, Table 3). The ANOVA analysis identified this change as being statistically significant (Table 4), but with no significant differences induced by the development level of the urban area. The decrease in Centrality expresses an increase of distance between the city centre and the new built-up areas as a result of both linear development along the transport routes, and occurrence of new built-up areas far from the urban centre. Higher decreases were recorded by Cluj Napoca, Oradea, Bacău (DL 1 urban areas), and by Suceava and Brăila (DL 2).

Compactness $(\mathrm{Cl})$ values have best highlighted the urban form variance induced by different development levels (Fig. 3). Overall, urban areas with a DL 1 recorded significantly lower values of compactness, regardless of considered time step (Table 4). The values suggest a higher fragmentation of built-up patches.

The trend of $\mathrm{Cl}$ values for urban areas of $\mathrm{DL} 1$ shows a dominant increase (i.e. decrease of patch fragmentation), most significant changes being recorded in Timișoara (Fig. 4). The trend is mainly due to the expansion of the city core, as built areas located in the near proximity (i.e. in the functional area) have been incorporated to it. For half of the DL 2 urban areas, the $\mathrm{Cl}$ values have remained constant between the two time steps (Table 3), while for the other half the values predominantly decreased. Significant changes were recorded in Sibiu (decrease of $\mathrm{Cl}$ values) and Bârlad (increase of $\mathrm{Cl}$ values).

Table 3

Number of urban areas in respect to the trend of the indicators

\begin{tabular}{|c|c|c|c|c|c|c|c|c|c|c|c|c|}
\hline \multirow[t]{2}{*}{$\begin{array}{c}\text { Development } \\
\text { level }\end{array}$} & \multicolumn{3}{|c|}{ CE } & \multicolumn{3}{|c|}{ Cl } & \multicolumn{3}{|c|}{ CILP } & \multicolumn{3}{|c|}{ ROS } \\
\hline & $\downarrow$ & $\uparrow$ & - & $\downarrow$ & $\uparrow$ & - & $\downarrow$ & $\uparrow$ & - & $\downarrow$ & $\uparrow$ & - \\
\hline DL 1 & 10 & 1 & 0 & 2 & 5 & 4 & 11 & 0 & 0 & 2 & 5 & 4 \\
\hline DL 2 & 17 & 1 & 0 & 6 & 3 & 9 & 17 & 0 & 1 & 4 & 6 & 8 \\
\hline Total & 27 & 2 & 0 & 8 & 8 & 13 & 28 & 0 & 1 & 6 & 11 & 12 \\
\hline
\end{tabular}

The symbols show: $\downarrow$ decrease of the index; $\uparrow$ increase of the index; - constant values.

The box plots (Fig. 3) and the ANOVA results (Table 4) on CILP values revealed significant differences between city cores, both due to development level and dynamics over time. Overall, the city cores of DL 1 type shown a higher fragmentation of the periphery, but over time the fragmentation tended to widen for both categories. Significant decreases were recorded in Galați (DL 1 urban area), Sebeș and Botoșani (DL 2 urban areas).

Porosity values (ROS) registered a slight increase for urban areas of DL 1 type and a decrease for those of DL 2 type (Table 3), but changes were not statistically significant (Table 4). 
Do Post-Socialist Urban Areas Maintain their Sustainable Compact Form ? Romanian Urban Areas as Case Study However, urban areas of DL 2 have higher porosity values, suggesting an increased proportion
of green and open spaces as compared to those of $D L 1$ type.

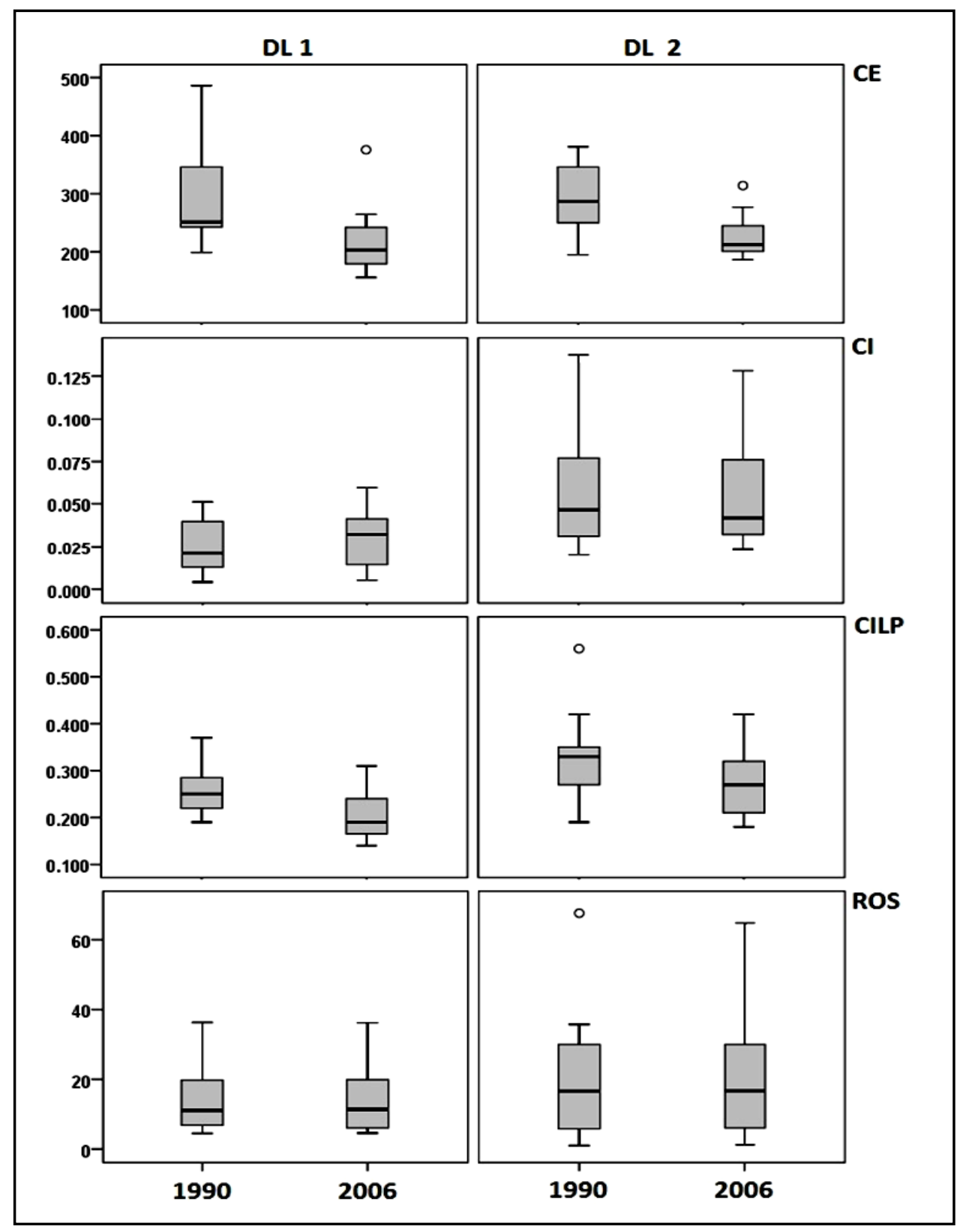

Fig. 3 - Dynamics of urban form indicators between 1990 and 2006, for urban areas with different development levels 
Simona Raluca GRĂDINARU, Cristian Ioan IOJĂ, Ileana PĂTRU-STUPARIU

Table 4

Results of two-way repeated-measurement ANOVA analysis

\begin{tabular}{|c|c|c|c|c|c|}
\hline \multicolumn{2}{|c|}{ Urban form indicator } & Factor & $\mathbf{F}$ & df & $p$ \\
\hline \multirow{3}{*}{ Centrality } & \multirow{2}{*}{ within subject effects } & time & 46.833 & 1 & $.000^{*}$ \\
\hline & & 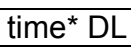 & 1.793 & 1 & .191 \\
\hline & between subjects effects & $\mathrm{DL}$ & .917 & 1 & .346 \\
\hline \multirow{3}{*}{$\mathrm{Cl}$} & \multirow{2}{*}{ within subject effects } & time & .456 & 1 & .505 \\
\hline & & time $^{*} \mathrm{DL}$ & 2.443 & 1 & .129 \\
\hline & between subjects effects & $\mathrm{DL}$ & 7.665 & 1 & $.010^{*}$ \\
\hline \multirow{3}{*}{ CILP } & \multirow{2}{*}{ within subject effects } & time & 49.807 & 1 & $.000^{*}$ \\
\hline & & time $^{*} \mathrm{DL}$ & .316 & 1 & .579 \\
\hline & between subjects effects & $\mathrm{DL}$ & 6.462 & 1 & $.017^{*}$ \\
\hline \multirow{3}{*}{ ROS } & \multirow{2}{*}{ within subject effects } & time & .095 & 1 & .760 \\
\hline & & time* DL & 1.905 & 1 & .178 \\
\hline & between subjects effects & DL & 1.130 & 1 & .297 \\
\hline
\end{tabular}

*statistically significant values

\section{Discussion on urban form changes in post-socialist Romania}

Post-socialist cities are a special case in the analysis of urban form dynamics. The transition from a centralized, top-down planning system to the one based on market economy led to important changes to the planning system (Benedek 2013), having a direct effect on the spatial structure of urban areas. By using Romanian urban areas as case study, our study aimed to highlight the urban form changes that cities and their functional areas faced, sixteen years after the fall of the socialist regime. The results showed a shift from the "inherited" compact city to a type of expansion dependent on the administrative and economic power of the city core.

The selected indicators allowed us to highlight specific processes related to the transformations of city cores and their functional areas (Jaeger et al. 2010). In the following paragraphs, we will discuss the processes connected to the urban form changes and we will further emphasize the need to restructure spatial planning at local and supra local level in order to respond to development challenges.

Periurbanization accentuated in Romanian urban areas, as shown by the decrease of CE and $\mathrm{Cl}$ values. This process highlights the pressure faced by functional areas (Schwarz 2010) as they become attractive due to lower taxes and land prices. One should bear in mind that functional areas with strong dynamics are mixed environments with a high degree of urbanization, but they are also rural in character. Many of the administrative units which are components of the functional areas do not have the financial capabilities to support the expansion of public utilities for the newly and rapidly developed built-up areas (lojă et al. 2011, lojă et al. 2014).

In line with the findings of Suditu et al. (2010), urban sprawl affects the vast majority of urban areas in Romania. The CE values show an increase of the distance between the city centre and the new built-up patches for all the analysed urban areas. However, the results showed that sprawl is more pronounced in urban areas of DL 1 type (Rank 0 and 1). The identified trend is similar to that observed by Stanilov (2007), who notes that in post-socialist countries the polarization of economic activities in large cities leads to them being more dynamic. The fact that these cities are the major centres of services, education, capital, know-how, and serve as "gates" to international markets, gives them an increasing role in the reorganization of 
economic activities and real estate market at national level (Stead and Nadin 2008).

The evolution of $\mathrm{Cl}$ values for $\mathrm{DL} 1$ type urban areas revealed an increase of compactness. However, the result should be interpreted in the context of new built-up development in continuation of the existing one. Most frequently, development involves the expansion of builtup land in the functional areas. Nevertheless, spatial continuity is separated by the administrative arrangements (see Fig. 4, north of Timișoara).

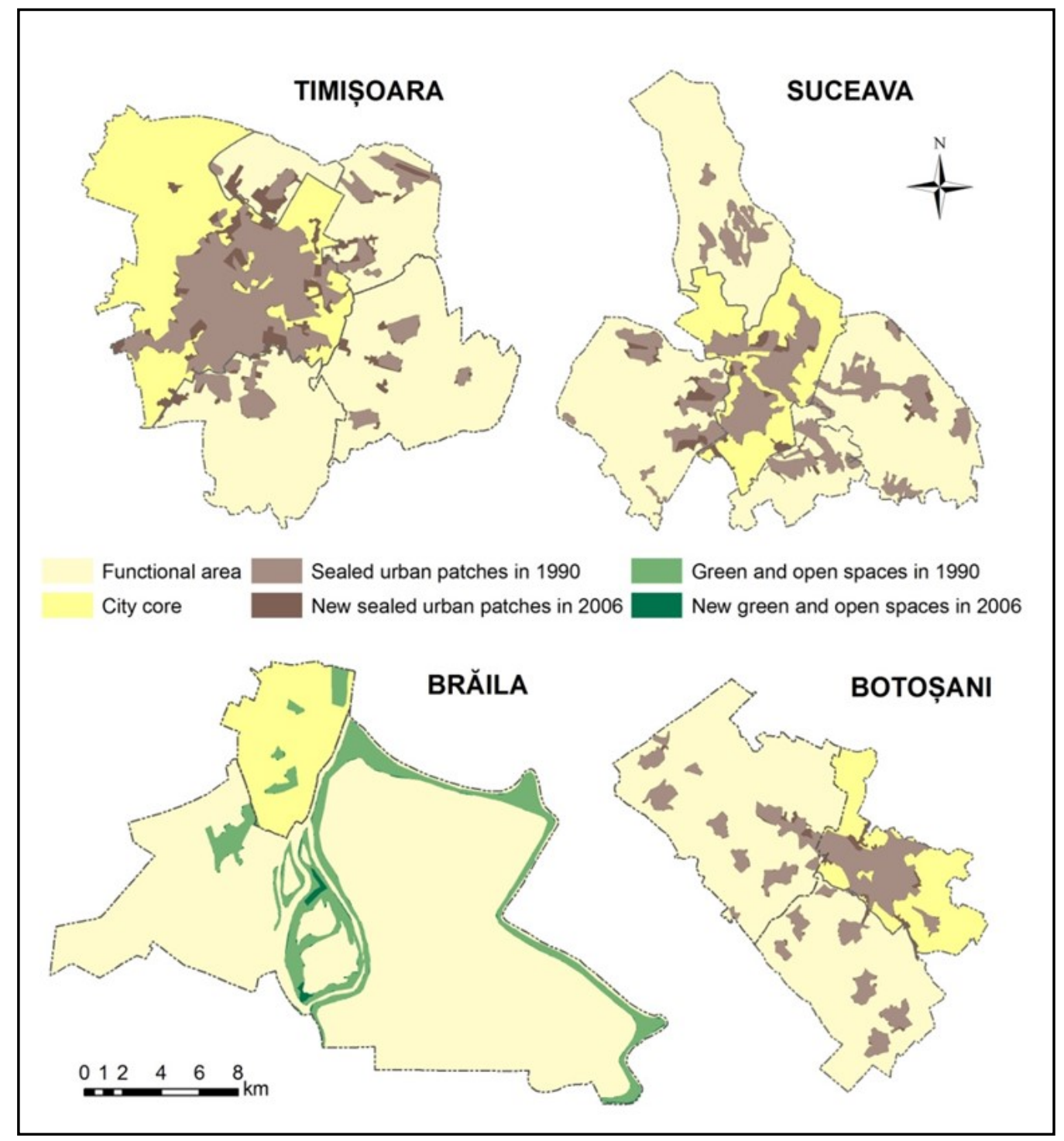

Fig. 4 - Dynamics of sealed urban patches and green and open spaces in four urban areas in Romania 
In $45 \%$ of cases, compactness values remained constant between the two time steps, the share of urban areas with this trend being higher for GD2 type cities. Although it does not provide an overview of urban growth, such values might indicate two possibilities: a) the positive impact of sustainable local policies on urban planning, or b) no significant increase of the built-up areas. Salvati (2013) indicates that under the influence of self-contained urban growth policies, urban areas which were historically compact are more likely to maintain their form over time. We recommend further research in this regard, in order to correlate the findings with local strategies of densification, urban conversion or urban regeneration.

The dynamics of CILP values highlight that suburbanization affects both large and mediumsized urban areas. Under the pressure of private investors and encouraged by the local authorities, as they saw it as a way to increase their budget, this process became characteristic to post-socialist cities (Sýkora and Ourednek 2007). In Romania, suburbanization is a severe threat to the sustainable development of the urban landscape due to its connections with exception driven urbanism, abandonment of agricultural land (Grădinaru et al. 2015) and excessive development in areas with low connection to public transportation. The effective control of suburban built-up expansion cannot be achieved as long as the national legislation permits the incremental increase of built-up areas (every 2-3 years), allowing for constant exemptions from the urban plans that are in force.

Even though lower porosity values for DL 1 urban areas indicate less sustainability, they must be analysed in a spatial context. The location of DL 1 urban areas in the plains, mainly involves an increased share of agricultural land in the functional areas. This is in contrast to the DL 2 urban areas, where the proximity to the Carpathians and Subcarpathians ensures high access to nearby green infrastructure.

The need to promote the sustainable development of urban areas is one of the focal points of urban planning at the European level. The European Commission (2014) points out that the unplanned expansion of compact cities compromises the advantages created through the efficient resources use. Furthermore, the Commission highlights the gap created by the differentiated planning of the urban centre and functional areas, and it recommends to focus planning on the functionality of urban areas as an optimal approach particularly where large cities are concerned (European Commission 2011).

As in Romania the horizontal collaboration between the authorities in the city core and the functional areas is rather weak, setting metropolitan areas as administrative bodies with decision power in spatial planning, or increasing the power of the existing ones, could become a step in the sustainable management of urban areas (lanoș et al. 2012). However, this involves the need to reconsider the relation between the city core and its functional area, and the legal and administrative status of suburban communes. As planning tool, the use of spatial framework plans at local level for guiding built-up development could be a solution to promote and coordinate sustainable development (Stead and Nadin 2008). Such plans could strengthen cooperation between the local authorities who adopted the plans, thus minimizing the adverse effects of unorganized development due to the competition for attracting funds and investments.

The analysis has some limitations that must be considered. The spatial availability of Corine Land Cover data allowed the inclusion of a sufficient number of urban areas to have an overview of the situation at national level. However, the spatial resolution of the data (i.e. minimum mapping unit $=25 \mathrm{ha}$ ) does not allow a detailed analysis. The use of aerial imagery and other cartographic materials with high resolution might reveal a higher fragmentation of built-up areas. The temporal resolution of the data set offered the possibility to analyse the urban form in two periods characterized by different spatial planning approaches: the end of the socialist period and 16 years later. However, as the economic crisis in 2008 affected the real estate 
market, and therefore the development of built-up areas (Grădinaru et al. 2015), more recent data might reveal new patterns. Since the Copernicus Program for monitoring land use at European level expects the validation and the launch of CLC 2012, the new dataset can be used for further research.

\section{Conclusions}

We showed that post-socialist urban areas either shifted from the compact form to more dispersed patterns, either expanded in a compact manner. Although specific processes of urban expansion, such as suburbanization or periurbanization, affect the vast majority of analysed cities, they are influenced by the development level of the urban area.

The DL 1 urban areas are more dynamic in terms of built-up development as compared to the smaller DL 2 urban areas. The much higher dispersion (e.g. sprawl) of DL 1 urban areas and the tendency to expand and incorporate the built-up land in the functional areas highlight the need to adopt alternative planning approaches. Efficient horizontal planning in the city core (officially, urban area) and its functional area (officially, rural communes) could be achieved by creating planning tools that strengthen their collaboration (e.g. functional metropolitan areas) (lanoş et al. 2012).

The dynamics of DL 2 urban areas highlighted two issues: a) although urban areas are less affected by sprawl, suburbanization is a process as active as in the DL 1 urban areas; and b) in DL 2 urban areas, urban form indicators showed a greater variability compared to DL 1, but for a large number of urban areas the values remained constant. Such differences highlight the fact that planning should be adapted to local circumstances and to the different development trajectories of mid-sized urban areas.

\section{Acknowledgements}

This work was supported by a grant from the Romanian National Authority for Scientific Research, CNDI-UEFISCDI PN-II-PT-PCCA-2011-3.2-0084.

\section{References}

AGUILERA F., VALENZUELA L. M., BOTEQUILHA-LEITÃO A. (2011), Landscape metrics in the analysis of urban land use patterns: A case study in a Spanish metropolitan area, Landscape and Urban Planning 99 (3-4), 226-238.

ANDERSON W. P., KANAROGLOU P. S., MILLER E. J. (1996), Urban Form, Energy and the Environment: A review of Issues, Evidence and Policy, Urban Studies 33 (1), 7-35.

ARRIBAS-BEL D., NIJKAMP P., SCHOLTEN H. (2011), Multidimensional urban sprawl in Europe: a self-organizing map approach, Computers, Environment and Urban Systems 35 (4), 263-275.

BENEDEK J. (2013), The spatial planning system in Romania, Romanian Review of Regional Studies 9 (2), 23-30.

BRETAGNOLLE A., DELISLE F., MATHIAN H., LIZZI L., GUÉROIS M., AVERLANT G. (2011), LUZ Specifications. Urban Audit 2004. Technical Report, ESPON, Luxembourg. BURTON E. (2002), Measuring urban compactness in UK towns and cities, Environment and Planning B: Planning and Design 29 (2), 219-250.

CAMAGNI R., GIBELLI M. C., RIGAMONTI P. (2002), Urban mobility and urban form: the social and environmental costs of different patterns of urban expansion, Ecological Economics 40 (2), 199-216.

CHEN H., JIA B., LAU S. S. Y. (2008), Sustainable urban form for Chinese compact cities: Challenges of a rapid urbanized economy, Habitat International 32 (1), 28-40. 
CHEVAL S., DUMITRESCU A. (2009), The July urban heat island of Bucharest as derived from MODIS images, Theoretical and applied climatology 96 (1), 145-153.

DEMPSEY N., BROWN C., RAMAN S., PORTA S., JENKS M., JONES C., BRAMLEY G. (2010), Elements of Urban Form, in: JENKS M., JONES C. (eds.), Dimensions of the Sustainable City, Volume 2, Springer, London, pp. 21-51.

ECHENIQUE M. H., HARGREAVES A. J., MITCHELL G., NAMDEO A. (2012), Growing cities sustainably. Does urban form really matter? Journal of the American Planning Association 78 (2), 121-137.

EEA (2013a), Corine Land Cover 1990 raster data, Version 17 (12/2013) - Raster data on land cover for the CLC1990 inventory, European Environment Agency, Retrieved from: www.eea.europa.eu.

EEA (2013b), Corine Land Cover 2006 seamless vector data, Version 17 (12/2013), European Environment Agency, Retrieved from: www.eea.europa.eu.

ELKIN T., MCLAREN D., HILLMAN M. (1991), Reviving the City: towards sustainable urban development, Friends of the Earth, London.

EUROPEAN COMMISSION (1990), Green Paper on the Urban Environment, Commission of the European Communities, Brussels.

EUROPEAN COMMISSION (1999), ESDP - European Spatial Development Perspective. Towards Balanced and Sustainable Development of the Territory of the European Union, Office for Official Publications of the European Communities, Luxembourg.

EUROPEAN COMMISSION (2011), Territorial Agenda of the European Union 2020. Towards an Inclusive, Smart and Sustainable Europe of Diverse Regions, Retrieved from: www.mmr.cz.

EUROPEAN COMMISSION (2014), The urban dimension of EU policies - key features of an EU urban agenda, Retrieved from: www.eur-lex.europa.eu.

FARMANI R., BUTLER D. (2014), Implications of urban form on water distribution systems performance, Water Resources Management 28 (1), 83-97.

FIELD A. (2009), Discovering statistics using SPSS, SAGE Publications Ltd, London.

GALSTER G., HANSON R., RATCLIFFE M. R., WOLMAN H., COLEMAN S., FREIHAGE J. (2001), Wrestling sprawl to the ground: defining and measuring an elusive concept, Housing Policy Debate 12 (4), 681-717.

GOTELLI N. J., ELLISON A. M. (2013), A primer of Ecological Statistics, Second Edition, Sinauer Associates, Sunderland, Massachusetts USA.

GRĂDINARU S. R., IOJĂ C. I., ONOSE D. A., GAVRILIDIS A. A., PĂTRU-STUPARIU I., KIENAST F., HERSPERGER A. M. (2015), Land abandonment as precursor of built-up development at the sprawling periphery of former socialist cities, Ecological Indicators 57, 305-313.

GRIMM N. B., FAETH S. H., GOLUBIEWSKI N. E., REDMAN C. L., WU J., BAI X., BRIGGS J. M. (2008), Global change and the ecology of cities, Science, 319 (5864), 756-760.

GUSDORF F., HALLEGATTE S. (2007), Compact or spread-out cities: Urban planning, taxation, and the vulnerability to transportation shocks, Energy Policy 35 (10), 4826-4838.

HALLEUX J.-M., MARCINCZAK S., VAN DER KRABBEN E. (2012), The adaptive efficiency of land use planning measured by the control of urban sprawl.The cases of the Netherlands, Belgium and Poland, Land Use Policy 29 (4), 887-898.

HIRT S. (2013), Whatever happened to the (post)socialist city? Cities 32 (Supplement 1), S29-S38.

HUANG J., LU X. X., SELLERS J. M. (2007), A global comparative analysis of urban form: Applying spatial metrics and remote sensing, Landscape and Urban Planning 82 (4), 184-197.

IANOŞ I., PEPTENATU D., DRĂGHICI C., PINTILII R. D. (2012), Management elements of the emergent metropolitan areas in a transition country. Romania, as case study, Journal of Urban and Regional Analysis 4 (2), 149-172. 
IOJĂ C. I., NIȚĂ M. R., VÂNĂU G. O., ONOSE D. A., GAVRILIDIS A. A. (2014), Using multi-criteria analysis for the identification of spatial land-use conflicts in the Bucharest Metropolitan Area, Ecological Indicators 42, 112-121.

IOJĂ I. C., ONOSE D. A., NIŢĂ M. R., VÂNĂU G. O., PĂTROESCU M., GAVRILIDIS A. A., SAGHIN I., ZAREA R. (2011), The conversion of agricultural lands into built surfaces in Romania, Recent Researches in Urban Sustainability and Green Development 6, 115-120.

JABAREEN Y. R. (2006), Sustainable urban forms. Their typologies, models and concepts, Journal of Planning Education and Research 26 (1), 38-52.

JAEGER J. A. G., BERTILLER R., SCHWICK C., KIENAST F. (2010), Suitability criteria for measures of urban sprawl, Ecological Indicators 10 (2), 397-406.

JENKS M., BURGESS R. (eds.) (2000), Compact cities: sustainable urban forms for developing countries, Taylor \& Francis, London.

MILEGO R. (2007), Urban Morphological Zones 2000. Definition and procedural steps (Version F1v0), European Environment Agency, Retrieved from: www.eea.europa.eu.

MUNIER N. (2011), Methodology to select a set of urban sustainability indicators to measure the state of the city, and performance assessment, Ecological Indicators 11 (5), 1020-1026.

NATIONAL ASSEMBLY (1968), Law 2/1968 regarding the administrative organisation of the Socialist Republic of Romania, Retrieved from: www.cdep.ro (in Romanian).

NIS (2013), Romania's contribution to the Urban Audit project, National Institute of Statistics, Retrieved from: www.insse.ro (in Romanian).

PETRIŞOR A. I. (2010), The Theory and Practice of Urban and Spatial Planning in Romania: Education, Laws, Actors, Procedures, Documents, Plans, and Spatial Organization. A Multiscale Analysis, Serbian Architectural Journal 2 (2), 139-154.

PETRIŞOR A.-I., IANOŞ I., TĂLÂNGĂ C. (2010), Land cover and use changes focused on the urbanization processes in Romania, Environmental Engineering and Management Journal 9 (6), 765-771.

ROMANIAN GOVERNMENT (2001), Law no. 351/2001 on the Aproval of the Spatial Planning of the National Territory Document. Section IV - Human Settlements Network (updated version), Retrieved from: www.cdep.ro (in Romanian).

SALVATI L. (2013), Urban containment in action? Long-term dynamics of self-contained urban growth in compact and dispersed regions of southern Europe, Land Use Policy 35, 213-225.

SCHWARZ N. (2010), Urban form revisited - Selecting indicators for characterising European cities, Landscape and Urban Planning 96 (1), 29-47.

SCOFFHAM E., MARAT-MENDES T. (2013), The 'ground rules' of sustainable urban form, in: WILLIAMS K., BURTON E., JENKS M. (eds.), Achieving Sustainable Urban Form, Routledge, New York, pp. 97-106.

STANILOV K. (2007), Urban development policies in Central and Eastern Europe during the transition period and their impact on urban form, in: STANILOV K. (ed.), The Post-Socialist City, Springer, Dordrecht, pp. 347-359.

STEAD D., NADIN V. M. (2008), Spatial Planning - Key instrument for Development and Effective Governance with Special Reference to Countries in Transition, United Nations, Geneva.

SUDITU B., GINAVAR A., MUICĂ A., IORDĂCHESCU C., VÂRDOL A., GHINEA B. (2010), Urban sprawl characteristics and typologies in Romania, Human Geographies 4 (2), 79-87.

SÝKORA L., OUREDNEK M. (2007), Sprawling post-communist metropolis: commercial and residential suburbanization in Prague and Brno, the Czech Republic, in: Razin E., Dijst M., Vázquez C.(eds.), Employment Deconcentration in European Metropolitan Areas, Springer, Dordrecht, pp. 209-233. New York.

WALDHEIM C. (2006), The landscape urbansim reader, Princeton Architectural Press, 
ZHAO P. (2010), Sustainable urban expansion and transportation in a growing megacity: Consequences of urban sprawl for mobility on the urban fringe of Beijing, Habitat International 34 (2), 236-243.

ZHOU J., SHEN L., SONG X., ZHANG X. (2015), Selection and modeling sustainable urbanization indicators: A responsibility-based method, Ecological Indicators 56, 87-95.

Initial submission: 04.07.2015

Revised submission: 07.11.2015

Final acceptance: 04.12.2015

Correspondence: Centre for Environmental Research and Impact Studies, University of Bucharest, 1 Nicolae Balcescu Blv., 010041, Sector 1, Bucharest, Romania.

E-mail: simona.gradinaru@g.unibuc.ro 